
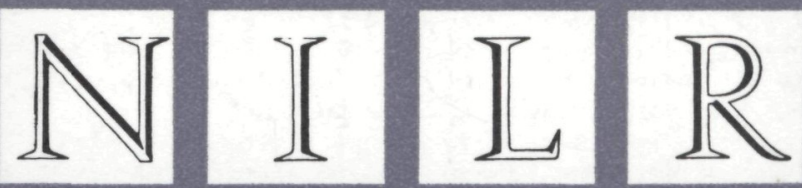

NETHERLANDS

INTERNATIONAL

LAW

REVIEW

INTERNATIONAL LAW

CONFLICT OF LAWS

COMPARATIVE LAW

1985-VOL.XXXII-ISSUE 2

MARTINUS NIJHOFF PUBLISHERS 


\section{BOARD OF EDITORS}

M. BOS, Emeritus Professor of Public International Law, University of Utrecht J.E.J.TH. DEELEN, Professor of Comparative and Private International Law, Tilburg School of Economics, member of the Netherlands Standing Government Committee on Private International Law

H. DUINTJER TEBBENS, Research Officer, European Court of Justice, Luxembourg

L. ERADES, Former Vice-President of the District Court at Rotterdam, Editorin-Chief

C. FLINTERMAN, Professor of Law, University of Limburg, Maastricht

E.H. HONDIUS, Professor of Civil Law, University of Utrecht

P.H. KOOIJMans, Professor of Public International Law, University of Leyden

\begin{abstract}
A.M. STUYT, Emeritus Professor of Public International Law, Catholic University of Nijmegen

M. SUMAMPOUW, Head of the Private International Law Department, Asser Instituut, The Hague

J.P. VERHEUL, Professor of Private International Law, University of Leyden C.C.A. VOSKUIL, Director of the Asser Instituut, The Hague, member of the Netherlands Standing Government Committee on Private International Law J.A. WADE, Deputy Director of the Asser Instituut, The Hague

P. MORRIS, Asser Instituut, The Hague, Executive Editor

M.H.A. VAN DER ARK - PIEKAAR, Secretary Private International Law Department, Asser Instituut, The Hague, Secretary to the board of Editors
\end{abstract}

Authors are requested to send three copies of each manuscript to the Secretariat: P.O. Box 30461, 2500 GL The Hague, The Netherlands.

The views expressed in any article are those of the individual author and do not necessarily represent the views of the Board of Editors.

Published three times a year, complemented by the Netherlands Yearbook of International Law, in co-operation with the T.M.C. Asser Instituut (22, Alexanderstraat, The Hague, phone (0)70-630900), an interuniversity institute founded in 1965 by eight Dutch universities offering courses in international law. The Institute is responsible for the promotion of education and research in international law, particularly by setting up documentation projects and carrying out research programmes in the fields covered by the three departments of the Institute: Private International Law, Public International Law and Law of the European Communities.

Combined annual subscription to the Netherlands International Law Review and to the Netherlands Yearbook of International Law Dfl. 200.00/US $\$ 80.00$, postage and handling Dfl. 30.00 / US $\$ 12.00$. Single copies of the Yearbook Dfl. 120.00/US \$ 39.25. Subscription orders and requests for specimen copies should be sent to Kluwer Academic Publishers Group, Distribution Center, P.O. Box 322, 3300 AH Dordrecht, The Netherlands.

Advertising: full page only; Dfl. $600,-$ per page; size $120 \mathrm{~mm} \times 200 \mathrm{~mm}$. Material: originals or camera-ready copy; closing dates: two months prior to month of publication; advertising copy to be sent to Kluwer Academic Publishers Group, Promotion Department, P.O. Box 989, 3300 AZ Dordrecht, The Netherlands.

() T.M.C. Asser Instituut and contributors.

All rights reserved. No part of this publication may be reproduced, stored in a retrieval system, or transmitted in any form or by any means, electronic, mechanical, photocopying, recording or otherwise, without the prior permission of the copyright-owners.

\section{FOR PHOTOCOPYING WITHIN THE USA}

The appearance of the code at the bottom of the first page of an article in this journal indicates the copyright owner's consent that copies of the article may be made for personal or internal use, or for the personal or internal use of specific clients. This consent is given on the condition, however, that the copier pays the stated per-copy fee through the Copyright Clearance Center, Inc., P.O. Box 765, Schenectady, New York 12301, USA for copying beyond that permitted by Sections 107 and 108 of the US Copyright Law.

ISSN 0028-2138

Second-class postage paid at New York, NY.

US Mailing-Agent: Expediters of the Printed World Ltd., 527 Madison Avenue, Suite 1217, New York, NY 10022 
NETHER LA N D I N TER NATIONA L LA W REVIEW VOL. XXXII 1985/2

\section{CONTENTS}

\section{Articles}

H.H. KIRCHHEINER, The National Ombudsman in a Democratic Perspective

J.B.J.M. TEN BERGE, The National Ombudsman in the Netherlands

J.A.W. LENSING, Some Comparative Aspects of the Protection of the Accused during his Interrogation in Preliminary Investigations

A.A. MAJID, Jural Aspects of Unauthorised Entry into Foreign Airspace

\section{Notes and Shorter Articles}

W.A. TIMmERmans, The Baltic States, the Soviet Union and the

Netherlands: a Historical Note

Documents

National Ombudsman Act

Information Concerning the Hague Convention on Private International Law

\section{Book Reviews}

Luigi Migliorino, Il recupero degli oggetti storici ed archeologici sommersi nel diritto internazionale (H.N. Boon)

Maarten Bos, A Methodology of International Law (L.E.)

\section{A.L. van den Bergh, Praktijk en Internationale Gewoonteregelvorming} (P.J. Kuyper)

Pieter VerLoren van Themaat, The Changing Structure of International Economic Law (B.V.A. Röling $\dagger$ )

S. Gruber-Magitot, Les conflicts de coutumes en matière de contracts dans la jurisprudence des Parlements, de Dumoulin au Code civil (J.G. Sauveplanne)

\section{Book Notices}

J.H.P. Boudewijnse, De Aansprakelijkheid van de Vervoerder volgens het Internationale Verdrag betreffende het Goederenvervoer per Spoorweg (CIM) (I.H.Ph. Diederiks-Verschoor)

Haim H. Cohn, Human Rights in Jewish Law (Bruce Hurwitz)

William C. Gilmore, The Grenada Intervention: Analysis and Documentation (Bruce Hurwitz)

Isabel Jalles, Antonio de Vasconcelos Porto (Ed.), Assuntos Europeus (J.J.M. Tromm) 
Jacques Naveau, Droit du Transport Aérien International

(J.J.M. Tromm)

Philippa Watson, Social Security Law of the European Communities (J.J.M. Tromm)

Books Received 